\title{
PERAN KEMAMPUAN KOMUNIKASI TERHADAP SIKAP PERCAYA DIRI SISWA SEKOLAH DASAR
}

\section{Lulu Luckyta, Astri Sutisnawati, dan Din Azwar Uswatun}

Universitas Muhammadiyah Sukabumi

Email: luckytalulu@gmail.com astri212@ummi.ac.id dinazwar@ummi.ac.id

\section{Info Artikel}

Sejarah Artikel:

Diserahkan 16 Juli 2020

Direvisi 17 Juli 2020

Direvisi 27 Oktober 2020

Disetujui 27 Oktober 2020

\section{Keywords:}

communications self confidence,

elementary students

\begin{abstract}
This research aims to describe the role of communication skills on the confident attitude of students in Negeri 1 Selabintana Elementary School.

The method used in this study is qualitative-descriptive referring to the Miles design pattern \& Huberman. The results of research analysis are obtained through field observation data retrieval techniques, and structured interviews, interviews are conducted with both informant namely high class teachers in state Elementary School 1 Selabintana. The results show that the students ' communication skills in the learning process are said to be good, whether referred to here is the students are able to convey the meaning of the message that they want to convey to the communicable by behave as it should be: directed, structured, clear in speaking or articulating articulation, regulating the use of language, language tone, appreciative of disagreements This communication skill has an impact on increasing student confidence in the final outcome of learning with maximum.
\end{abstract}

\begin{abstract}
Abstrak
Penelitian ini bertujuan untuk mendeskripsikan peran kemampuan komunikasi terhadap sikap percaya diri siswa di Sekolah Dasar Negeri 1 Selabintana.

Metode yang digunakan dalam penelitian ini adalah kualitatif-deskriptif yang merujuk pada pola desain Miles\&Huberman. Hasil analisis penelitian didapat melalui teknik pengambilan data observasi lapangan, dan wawancara terstruktur, wawancara dilakukan dengan kedua informan yaitu guru kelas tinggi di Sekolah Dasar Negeri 1 Selabintana.

Hasil penelitian menunjukkan bahwa kemampuan komunikasi siswa dalam proses pembelajaran dikatakan baik, baik yang dimaksud disini adalah siswa sudah mampu menyampaikan maksud pesan yang ingin mereka sampaikan kepada komunikan dengan berperilaku sebagaimana mestinya, terarah, tertstruktur, jelas dalam berbicara atau menguasi artikulasi, mengatur penggunaan bahasa, nada bahasa, menghargai adanya perbedaan pendapat. Kemampuan komunikasi memberikan dampak pada meningkatnya sikap percaya diri siswa pada hasil akhir pembelajaran dengan maksimal.
\end{abstract}




\section{PENDAHULUAN}

Kegiatan interaksi manusia terjadi dalam segala segi kehidupan. Berbagi informasi, bertukar informasi, dan menjalin hubungan kerja sama termasuk ke dalam kegiatan interaksi manusia. Interaksi terjadi akibat dari komunikasi. Menurut Inah (2013) komunikasi adalah proses penyampaian pesan dari komunikator kepada komunikan atau audiens baik dalam bentuk simbol, lambang dengan harapan bisa membawa atau memahamkan pesan itu kepada masyarakat serta berusaha mengubah sikap dan tingkah laku itu. Dapat disimpulkan komunikasi adalah kegiatan yang dilakukan oleh komunikator sebagai penyampai pesan kepada komunikan sebagai penerima pesan. Komunikasi bertujuan untuk saling menyampaikan informasi, bertukar informasi melalui tatap muka langsung atau dengan menggunakan media tidak langsung seperti telepon, chatting, sehingga pesan tersebut dapat dipahami guna untuk mendapat respon balik yang mengandung unsur makna kesamaan.

Komunikasi selalu terjadi di berbagai kegiatan salah satunya dalam kegiatan pembelajaran sekolah. Menurut Kariani (2014) pembelajaran merupakan suatu proses yang sangat penting dalam pendidikan. Pembelajaran adalah proses interaksi siswa dengan pendidik dan sumber belajar pada suatu lingkungan belajar. Dalam proses pembelajaran terdapat proses transfer pengetahuan dari guru kepada siswa melalui komunikasi. Komunikasi dalam pembelajaran diartikan dengan cara yang dilakukan oleh pendidik untuk menyampaikan berbagai macam isi materi pembelajaran kepada siswa dengan menggunakan berbagai macam media, metode, model pembelajaran untuk menciptkan suasana aktif belajar. Menurut Marfuah (2017) kemampuan berkomunikasi menjadi syarat penting dalam proses pembelajaran karena dapat membantu dan memfasilitasi siswa untuk mengutarakan gagasan, serta bertukar informasi dengan guru atau sesama siswa lain. Peran komunikasi dalam proses pembelajaran berpengaruh kepada sikap yang akan ditimbulkan oleh siswa itu sendiri, salah satunya adalah peningkatan sikap rasa percaya diri.

Marfuah (2017) mengungkapkan bahwa peserta didik yang pasif dalam proses pembelajaran ketika dimintai argument pada saat diskusi akan menunjukkan sikap percaya diri yang kurang dan merasa khawatir argumentasinya keliru, bersikap masa bodoh karena temannya sudah menjawab pertanyaan, sehingga peserta didik akan merasa benar-benar tidak memahami materi dan membuat hasil belajarnya menjadi rendah. Pemilihan model, strategi pembelajaran yang bervariasi dipilih pendidik untuk menciptakan suasana aktif belajar guna meningkatkan kemampuan komunikasi yang berdampak kepada sikap percaya diri siswa.

Kepercayaan diri akan memperkuat motivasi mencapai keberhasilan, karena semakin tinggi kepercayaan terhadap kemampuan diri sendiri, semakin kuat pula semangat untuk menyelesaikan pekerjaanya (Hendriana, 2014). Disampaikan juga oleh Hakim dalam Aristiani (2016) bahwa rasa percaya diri merupakan suatu keyakinan terhadap segala aspek yang dimiliki dan keyakinan tersebut membuatnya merasa mampu untuk bisa mencapai tujuan yang telah ditetapkan. Peningkatan rasa percaya diri dan motivasi belajar siswa dikatakan berhasil jika mereka mampu menerapkan hal-hal apa yang telah dipelajari selama proses pembelajaran (Trianto 2010).

Kepercayaan diri terdiri atas dua sumber, yakni internal dan eksternal (Hendriana, 2014). Sumber internal, berarti kepercayaan diri itu berasal dari dirinya sendiri. Ia percaya bahwa dirinya mempunyai dasar pemahaman yang baik untuk bidang tertentu misalnya dalam proses belajar. Sumber internal semacam ini dapat dipengaruhi oleh dorongan dari luar pula. Orang yang belum mempunyai rasa kepercayaan diri kuat, akan mudah terpengaruh oleh reaksi eksternal (yang berasal dari luar dirinya) terhadap apa yang sedang dilakukannya. Orang yang kepercayaan dirinya kurang, biasanya akan menjadi peka terhadap pembicaraan mengenai diri atau prestasinya dan hal semacam ini pasti akan mempengaruhi pelaksanaan kerjanya. Sumber eksternal meliputi lingkungan, misalnya sikap orang lain, pujian, kritikan, dan semacamnya

Hasil observasi yang dilakukan di SD N 1 Selabintana ditemui bahwa rendahnya komunikasi siswa terjadi ketika guru hendak memberikan kesempatan kepada mereka untuk berperan aktif dalam pembelajaran seperti bertanya, mengemukakan pendapat, ide-ide, siswa lebih sering untuk menjawab dengan serentak dan ketika guru meminta untuk menjawab secara individu dengan mengangkat tangan siswa lebih sering ragu-ragu dan diam, mereka justru terkesan acuh. Selain itu, kesenjangan perilaku siswa ketika berkomunikasi dalam proses pembelajaran terlihat ketika guru sedang menyampaikan isi materi pembelajaran mereka bersikap diam, tidak melibatkan diri dalam pembelajaran, hal ini dipicu karena mereka 
Lulu Luckyta, Astri Sutisnawati, dan Din Azwar Uswatun

PERAN KEMAMPUAN KOMUNIKASI SISWA TERHADAP SIKAP PERCAYA DIRI SISWA ....

WASIS: Jurnal Ilmiah Pendidikan. Volume 1 Nomor 2, November 2020, hlm. 68-73

tidak berani dan percaya diri untuk menyuarakan pendapat, ide-ide, dan gagasan. Melihat bagaimana kondisi dilapangan, maka penelitian ini dilakukan dengan tujuan mendeskripsikan peran kemampuan komunikasi siswa terhadap sikap percaya diri siswa.

\section{METODE PENELITIAN}

Jenis penelitian ini adalah penelitian kualitatif dengan metode kualitatif deskriptif. Masalah yang ditimbulkan bersifat alami sesuai dengan karakteristik penelitian kualitatif (Sugiyono, 2015). Penelitian kualitatif sebagai riset yang bersifat deskriptif dan cenderung menggunakan analisis dengan pendekatan induktif (Rukin, 2019). Desain dalam penelitian ini menggunakan desain deskriptif-kualitatif. Pelaksanaan penelitian dilakukan di SD N 1 Selabintana yang beralamat di Jln. Selabintana no.212 Warnasari Kecamatan Sukabumi, Kab. Sukabumi, Provinsi Jawa Barat. SDN 1 Selabintana dipilih sebagaimana peneliti melakukan magang (praktek mengajar) dan ditemukannya masalah. Penelitian dilakukan pada tanggal 06 Juli 2020 hingga 11 Juli 2020.

Teknik pengambilan data menggunakan observasi dan wawancara. Observasi dilakukan secara langsung dan wawancara dilakukan secara online kepada informan. Subyek data penelitian ini adalah wali kelas V A, B dan seluruh siswa di kelas V B dengan total siswa 31 yang terdiri dari 18 siswa laki-laki dan 13 siswa perempuan. Analisis data menggunakan model Miles dan Huberman yaitu reduksi data, penyajian data, dan penarikan kesimpulan.

\section{HASIL DAN PEMBAHASAN}

Berdasarkan hasil wawancara dan observasi yang telah dilakukan, peneliti menemukan bahwa siswa yang memiliki kemampuan komunikasi baik dalam proses pembelajaran ditunjukkan selama kegiatan pembelajaran berlangsung mereka berperilaku sebagaimana mestinya. Hal ini dilihat dari hasil transkrip wawancara kedua informan yaitu wali kelas VA dan B menyampaikan bahwa:

"Pada umumnya siswa memiliki tata
krama, sopan dan santun ketika
berbicara dengan guru dan temannya,
namun ada beberapa siswa yang masih
memiliki etika yang kurang baik karena
pelanggaran sekolah. Misalnya, dengan
berbicara kurang sopan, menghina,
mengejek temannya yang dapat menimbulkan pertengkaran dengan teman lainnya. Hal ini dipicu karena kurangnya pemahaman terhadap etika berkomunikasi yang baik sehingga menimbulkan kesalahpahaman. “

Kemampuan komunikasi siswa dalam proses pembelajaran berjalan dengan baik, mereka senantiasa dapat berperan aktif, dengan sikap percaya diri ketika mengutarakan pendapat, ide-ide, dan gagasannya. Perilaku yang ditunjukkan siswa tersebut seperti: siswa bersikap sopan dan mempersiapkan diri ketika akan memulai berbicara, menghargai saat teman sedang berkomunikasi (tidak mengobrol, bermain, dan mengolok-olok siswa yang sedang berbicara). Akan tetapi, masih ditemui beberapa perilaku yang kurang sopan dan santun dari siswa saat berkomunikasi. Hal ini dapat menimbulkan adanya pertengkaran antar siswa sehingga perlu dilakukan pendekatan terhadap siswa tersebut sesuai dengan yang disampaikan oleh informan sebagai berikut.

"Saya melakukan pendekatan terhadap
siswa tersebut, dengan mengidentifikasi
latar belakang keluarganya. Selain itu
siswa tersebut sering saya ajak untuk
berbicara/berkomunikasi. Saya juga
mencoba menghubungi orang tua siswa,
dan melakukan bimbingan individu
terhadap siswa."

Guru memiliki peranan yang penting dalam mendidik siswa. Hasil penelitian menunjukkan bahwa guru senantiasa melakukan pendekatan secara konseling kepada siswa dengan mengidentifikasi latar belakang keluarga, berkomunikasi dengan orang tua. Sesuai dengan pernyataan yang dikemukakan oleh Adi (2013) bahwa konseling dilakukan guna untuk mendapatkan pemahaman diri yang lebih baik, kemampuan mengontrol diri, dan memperbaiki tingkah laku pada masa yang akan datang.

Ketercapaian sikap percaya diri siswa ketika berkomunikasi baik dengan teman ataupun dengan guru tentu tidak didapat secara langsung. Peranan guru sebagai role model bagi siswa nya akan mempengaruhi mereka dalam berperilaku. Hal ini selaras dengan pendapat Safitri (2019) bahwa tugas utama seorang guru adalah mendidik yang bertujuan untuk mengubah tingkah laku murid menjadi lebih baik. Seorang guru juga harus dapat menjadi teladan yang baik bagi murid-murid sehingga para murid dapat memiliki 
karakter yang sesuai dengan norma dan nilai yang berlaku dimasyarakat.

Perilaku saat berkomunikasi tumbuh karena adanya pembiasaan. Ardianti (2017) menyampaikan bahwa perilaku yang dilakukan secara terus menerus (terbiasa) dapat membentuk karakter seseorang. Pembiasaan dimaksudkan adalah kegiatan yang dilakukan secara berulangulang. Informan menyampaikan bahwa:

"Aturan yang ditetapkan seperti
berbicara yang sopan, mendengarkan
dan menyimak orang yang sedang
berbicara, mengangkat tangan ketika
akan menyela/menanggapi pembicaraan
orang lain, berbicara pada pokok
permasalahan, saling menghargai dan
mendukung jika adanya perbedaan
pendapat."

Guru menanamkan aturan atau etika kepada siswa ketika akan berkomunikasi. Hal ini bertujuan agar siswa dapat membiasakan berkomunikasi sesuai dengan tertib dalam berbicara. Menurut Zainiyati (2017) aturan dan norma yang menjembatani atau bahkan menjadi penghalang dalam suatu komunikasi khususnya dalam proses pembelajaran hendaknya menjadi perhatian seorang pendidik. Mengingat masalah aturan janganlah disampaikan dalam bentuk larangan kepada siswa, akan tetapi bagaimana guru bisa mengemas pesan dalam aturan. Berikut ini bagan peran guru dalam kemampuan komunikasi siswa terhadap kepercayaan diri siswa.

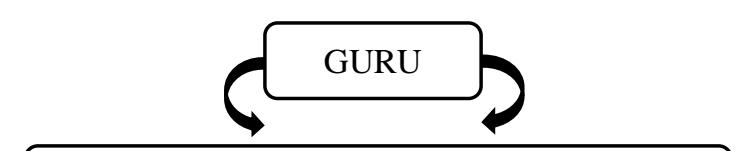

Penyampaian pesan/isi materi pembelajaran

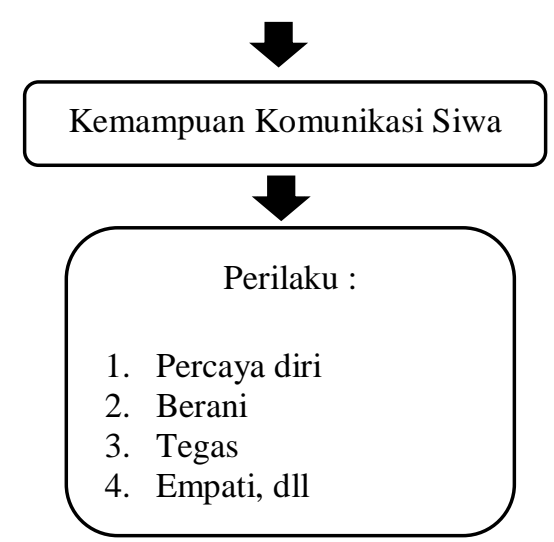

Gambar 1. Komunikasi terhadap perilaku siswa
Selama proses pembelajaran berlangsung perbedaan pendapat diantara siswa selalu terjadi. Hal tersebut mengakibatkan suasana selama proses pembelajaran terkesan tidak terarah, gaduh, dan tidak kondusif yang akan berdampak pada hasil akhir siswa dalam proses pembelajaran. Maka antisipasi yang dilakukan oleh guru yaitu dengan melakukan kompromi atas adanya perbedaan pendapat tersebut. Guru membuat berbagai aturan dan kesepakatan bersama agar siswa dapat bertanggung jawab tanpa menekankan aturan yang membuat siswa justru tidak bersikap baik, memotivasi siswa untuk mencari dan menemukan sumber perbedaan dan memecahkan permasalahannya bersama-sama, melakukan pendekatan partisipasif, memberikan kebebasan bagi siswa. Aturan tersebut seperti sebelum siswa memulai untuk berbicara mereka harus nyiapkan diri dengan baik, mengangkat tangan kanan ketika memulai pembicaraan, waktu yang diberikan siswa untuk berkomunikasi \pm 2 menit/siswa, ketika ada teman yang berbicara sikap siswa lainnya menyimak dengan seksama, menerima ketika adanya perbedaan pendapat, dan menerima jika ada masukan ataupun kritikan Hal ini digunakan untuk menjembatani agar tujuan dalam proses pembelajaran tercapai dengan baik dan siswa tentu akan mendapatkan hasil belajar yang baik pula.

Sikap percaya diri siswa akan tumbuh dan berkembang tergantung dari adanya dorongan keyakinan mereka untuk berani bersuara. Guru tentu berperan banyak untuk mewujudkan dorongan tersebut sehingga siswa dengan percaya diri mampu berkomunikasi. Dalam proses pembelajaran guru dituntut untuk kreatif memilih model pembelajaran yang menunjang pencapaian hasil belajar siswa. Pemilihan model pembelajaran yang bervariasi menjadi alternative guna dipilih oleh guru agar siswa memiliki motivasi untuk meningkatkan kemampuan komunikasi dalam proses pembelajaran. Rahayu (2015) menyampaikan bahwa penggunaan model pembelajaran dengan melibatkan siswa berdiskusi dan berani berpendapat dapat membantu siswa mengembangkan sikap percaya diri. Pemilihan model pembelajaran yang baik, sesuai, dan tepat dapat muwujudkan pencapaian pembelajaran yang maksimal. Selaras dengan pernyataan yang dikemukakan oleh Hamruni (2012) keberhasilan dalam pembelajaran di kelas tidak terlepas dari keterampilan guru dalam menyiapkan serta melakukan inovasi terhadap model pembelajaran yang akan diterapkan. Keberhasilan tersebut tentunya dapat terealisasi jika kedua belah pihak 
antara guru dan siswa sama-sama bekerja keras membangun komitmen bersama.

Keberhasilan komunikasi siswa dalam proses pembelajaran didorong oleh adanya faktor pendukung dan faktor penghambat. Pendukung kemampuan komunikasi siswa dilihat dengan kesamaan berbahasa, sikap rasa percaya diri, berani, berempati, lingkungan yang mendukung, teman sejawat, serta penggunaan alat peraga yang tepat dan sesuai untuk meningkatkan kemampuan komunikasi siswa. Faktor penghambat yang menjadi kendala guna meningkatnya kemampuan komunikasi seperti kelemahan berbahasa, rasa takut, tidak percaya diri, minimnya fasilitas yang digunakan dalam pembelajaran menyebabkan proses pembelajaran siswa jenuh, bosan sehingga siswa bersikap acuh, bahkan kemungkinan hasil dari pembelajaran didapat dengan tidak maksimal. Wakhyudin dan Putri (2020) menyampaikan bahwa kecamasan dalam berkomunikasi dapat menjadi salah satu factor menurunnya rasa percaya diri seseorang. Hal tersebut sesuai dengan yang disampaikan informan sebagai berikut.

\section{"Kemampuan komunikasi yang efektif membawa peran yang positif, meningkatkan kemampuan siswa pada proses pembelajaran sehingga ketercapaian dalam pembelajaran tercapai dengan maksimal, meningkatkan rasa percaya diri, melibatkan diri dengan aktif, memiliki rasa empati dengan menerima adanya perbedaan pendapat."}

Akan tetapi, kemampuan komunikasi akan memberikan dampak yang positif pada siswa mereka akan memiliki sikap percaya diri yang tinggi. Purnamasari (2016) berpendapat bahwa dengan keberanian mengkomunikasikan ide-ide kepada siswa lain, maka dapat meningkatkan pemahaman siswa. Apabila siswa berani mengutarakan pendapat, ide-ide, gagasan, dalam pembelajaran mereka akan berperan aktif sehingga akan mendukung tercapainya hasil belajar yang maksimal.

\section{SIMPULAN}

Berdasarkan penelitian yang dilakukan peneliti di SDN 1 Selabintana mengenai peran kemampuan komunikasi siswa terhadap sikap percaya diri dapat disimpulkan, kemampuan komunikasi siswa dalam proses pembelajaran dikelas sudah dapat dikatakan dengan baik, Siswa sudah mampu menyampaikan maksud pesan yang ingin mereka sampaikan kepada komunikan dengan berperilaku sebagaimana mestinya, terarah, tertstruktur, jelas dalam berbicara atau menguasi artikulasi, mengatur penggunaan bahasa, nada bahasa, menghargai adanya perbedaan pendapat. Kemampuan komunikasi tentu berdampak pada bagaimana mereka dengan percaya diri nya untuk mengemukakan pendapat, ide-ide, gagasan secara terarah dan dengan kemampuan komunikasi yang efektif siswa dapat meningkatkan hasil akhir pembelajaran dengan maksimal.

\section{DAFTAR PUSTAKA}

Ardianti S.D., Wanabuliandari S., \& Rahardjo S. (2017). Peningkatan Perilaku Peduli Lingkungan dan Tanggung Jawab Siswa Melalui Model EJAS Dengan Pendekatan Science Edutainmnet. Jurnal Ilmiah Pendidikan Dasar, $4(1): 1-7$

Aristiani, R. (2016). Meningkatkan Percaya Diri Siswa Melalui Layanan Informasi Berbantuan Audiovisual. Konseling GUSJIGANG, 2(2), 183.

Hendriana, H. (2014). Membangun Kepercayaan Diri Siswa Melalui Pembelajaran Matematika Humanis. Pengajaran MIPA, 19(1), 56.

Inah, E. (2013). Peranan Komunikasi dalam Pendidikan . Al-Ta'dib, 6(1), 180.

Purnamasari, S. \& Herman, T. (2016). Penggunaan Multimedia Interaktif Terhadap Peningkatan Kemampuan Pemahaman dan Komunikasi Matematis, Serta Kemandirian Belajar Siswa Sekolah Dasar. EduHumaniora: Jurnal Pendidikan Dasar, 8(2):178-185

Rahayu, R. (2015). Faktor-Faktor Yang Mempengaruhi Kepercayaan Diri Siswa Kelas VIII Dalam Menyelesaikan Masalah Matematika Pada Model PMRI. Jurnal Refleksi Edukatika, 5(2).

Rukin. (2019). Metodologi Penelitian Kualitatif. Sulawesi Selatan : Yayasan Ahmar Cendikia Indonesia.

Safitri, D. (2019). Menjadi Guru Profesional. Riau: PT. Indragiri Dot Com. 
Lulu Luckyta, Astri Sutisnawati, dan Din Azwar Uswatun

PERAN KEMAMPUAN KOMUNIKASI SISWA TERHADAP SIKAP PERCAYA DIRI SISWA ....

WASIS: Jurnal Ilmiah Pendidikan. Volume 1 Nomor 2, November 2020, hlm. 68-73

Sugiyono. (2015). Metode Penelitian Pendidikan

(Pendekatan Kuantitatif, Kualitatif, dan

$R n D)$. Bandung: Alfabeta.

Wakhyudin, H., \& Putri, A. D. S. (2020).

Analisis Kecemasan Mahasiswa Dalam

Menyelesaikan Skripsi. WASIS: Jurnal

Ilmiah Pendidikan, 1(1), 14-18.

Zainiyati. (2017). Pengembangan Media

Pembelajaran Agama Islam. Jakarta:

Kencana. 